\title{
Front Matter: Volume 6577
}

, "Front Matter: Volume 6577," Proc. SPIE 6577, Wireless Sensing and Processing II, 657701 (8 May 2007); doi: 10.1117/12.742609

SPIE Event: Defense and Security Symposium, 2007, Orlando, Florida, United SPIE. States 


\title{
PROCEEDINGS OF SPIE
}

\section{Wireless Sensing and Processing II}

\author{
Raghuveer M. Rao \\ Sohail A. Dianat \\ Michael D. Zoltowski \\ Editors
}

9 April 2007

Orlando, Forida, USA

Sponsored and Published by

SPIE-The International Society for Optical Engineering

Volume 6577 
The papers included in this volume were part of the technical conference cited on the cover and title page. Papers were selected and subject to review by the editors and conference program committee. Some conference presentations may not be available for publication. The papers published in these proceedings reflect the work and thoughts of the authors and are published herein as submitted. The publisher is not responsible for the validity of the information or for any outcomes resulting from reliance thereon.

Please use the following format to cite material from this book:

Author(s), "Title of Paper," in Wireless Sensing and Processing II, edited by Raghuveer M. Rao, Sohail A. Dianat, Michael D. Zoltowski, Proceedings of SPIE Vol. 6577 (SPIE, Bellingham, WA, 2007) Article CID Number.

ISSN 0277-786X

ISBN 9780819466990

Published by

SPIE-The International Society for Optical Engineering

P.O. Box 10, Bellingham, Washington 98227-0010 USA

Telephone 1 360/676-3290 (Pacific Time) · Fax 1 360/647-1445

http://www.spie.org

Copyright (@ 2007, The Society of Photo-Optical Instrumentation Engineers

Copying of material in this book for internal or personal use, or for the internal or personal use of specific clients, beyond the fair use provisions granted by the U.S. Copyright Law is authorized by SPIE subject to payment of copying fees. The Transactional Reporting Service base fee for this volume is $\$ 18.00$ per article (or portion thereof), which should be paid directly to the Copyright Clearance Center (CCC), 222 Rosewood Drive, Danvers, MA 01923. Payment may also be made electronically through CCC Online at http://www.copyright.com. Other copying for republication, resale, advertising or promotion, or any form of systematic or multiple reproduction of any material in this book is prohibited except with permission in writing from the publisher. The CCC fee code is 0277$786 \times / 07 / \$ 18.00$.

Printed in the United States of America. 


\section{Contents}

$\checkmark \quad$ Conference Committee

\section{SESSION 1 WIRELESS NETWORKS}

657702 A hybrid 802.16/802.11 network architecture for a United States coastal area network [6577-01]

J. L. Burbank, W. T. Kasch, J. Andrusenko, B. K. Haberman, R. Nichols, H. Zheng, The Johns Hopkins Univ. (USA)

657704 Code division controlled MAC in wireless sensor network by adaptive binary signature design [6577-03]

L. Wei, S. N. Batalama, D. A. Pados, State Univ. of New York at Buffalo (USA); B. Suter, Air Force Research Lab. (USA)

657705 Location-based route self-recovery for mobile ad hoc networks [6577-04]

S. Medidi, J. Wang, Washington State Univ. (USA)

657706 History-based route selection for reactive ad hoc routing protocols [6577-05]

S. Medidi, P. Cappetto, Washington State Univ. (USA)

\section{SESSION 2 SMART ANTENNAS}

657707 Approximate MLE algorithm for source localization based on TDOA measurements [6577-07]

G. GU, Lovisiana State Univ. (USA)

657708 Constrained Kalman filtering and its application to tracking of ground moving targets [6577-08]

G. GU, Lovisiana State Univ. (USA)

657709 Direction finding of GPS receiver interference based on the nulling weights [6577-09]

J. Wang, M. Amin, Villanova Univ. (USA)

Pagination: Proceedings of SPIE follow an e-First publication model, with papers published first online and then in print and on CD-ROM. Papers are published as they are submitted and meet publication criteria. A unique, consistent, permanent citation identifier (CID) number is assigned to each article at the time of the first publication. Utilization of CIDs allows articles to be fully citable as soon they are published online, and connects the same identifier to all online, print, and electronic versions of the publication. SPIE uses a six-digit CID article numbering system in which:

- The first four digits correspond to the SPIE volume number.

- The last two digits indicate publication order within the volume using a Base 36 numbering system employing both numerals and letters. These two-number sets start with 00, 01, 02, 03, 04, 05, 06, 07, 08, 09, 0A, 0B ... 0Z, followed by 10-1Z, 20-2Z, etc.

The CID number appears on each page of the manuscript. The complete citation is used on the first page, and an abbreviated version on subsequent pages. 
65770B A fast algorithm for direction of arrival estimation in multipath environments [6577-11] N. Tayem, M. Naraghi-Pour, Louisiana State Univ. (USA)

65770C Decoder-aided multidata detection of COFDM-CDMA waveforms on HF multipath/fading channels [6577-12]

J. Nieto, Harris Corp. (USA)

65770D Utilizing space frequency COFDM on multipath fading channels [6577-13]

F. C. Kellerman, Harris RF Communications (USA)

\section{SESSION 4 EMERGING SYSTEMS}

65770E A review of scale factors, fixed-point precision, soft decisions, and hard decisions on the performance of the UMTS (3GPP) turbo codes [6577-16]

J. Nieto, Harris Corp. (USA)

65770F UMTS-based data link and data network for telemetry and time space position information (TSPI) applications [6577-17]

R. Sivasankaran, W. Ferzali, G. Rajappan, Mayflower Communications Company, Inc.

(USA); A. Khosrowabadi, Edwards Air Force Base (USA)

$65770 \mathrm{G}$ Model selection and Kolmogorov-Smirnov test for ultrawideband channel modeling [6577-18]

D. Choudhary, A. Robinson, Univ. of Memphis (USA)

65770H Performance of chirp-slope keying with joint time-frequency detectors [6577-19]

I. X. Incer, E. J. Kaminsky, Univ. of New Orleans (USA)

65770 Anti-collusion fingerprinting scheme based on error correction ability of nonlinear combinatorial code [6577-20]

W. Huang, I. M. S. Panahi, Univ. of Texas at Dallas (USA)

\section{SESSION 5 SENSOR NETWORKS}

65770L Sensor networks and network sensibility [6577-14]

M. Li, Univ. of Waterloo (Canada); H. Lin, J. Rushing, S. J. Graves, Univ. of Alabama, Huntsville (USA)

Author Index 


\title{
Conference Committee
}

\author{
Symposium Chair \\ John C. Carrano, Luminex Corporation (USA) \\ Symposium Cochair
}

Larry B. Stotts, DARPA (USA)

Program Track Chair

Raghuveer M. Rao, Rochester Institute of Technology (USA)

Conference Chairs

Raghuveer M. Rao, Rochester Institute of Technology (USA)

Sohail A. Dianat, Rochester Institute of Technology (USA)

Michael D. Zoltowski, Purdue University (USA)

Program Committee

Moeness G. Amin, Villanova University (USA)

Braham Himed, Air Force Research Laboratory (USA)

Sirisha R. Medidi, Washington State University (USA)

John W. Nieto, Harris Corporation (USA)

Pramod K. Varshney, Syracuse University (USA)

Session Chairs

$1 \quad$ Wireless Networks

John W. Nieto, Harris Corporation (USA)

2 Smart Antennas

Raghuveer M. Rao, Rochester Institute of Technology (USA)

3 Multipath

Dimitris A. Pados, State University of New York at Buffalo (USA)

$4 \quad$ Emerging Systems

Sirisha R. Medidi, Washington State University (USA)

5 Sensor Networks

Fred C. Kellerman, Harris Corporation (USA) 
Downloaded From: https://www.spiedigitallibrary.org/conference-proceedings-of-spie on 26 Apr 2023

Terms of Use: https://www.spiedigitallibrary.org/terms-of-use 